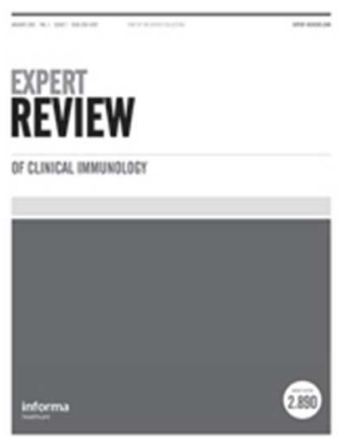

\title{
Recombinant Human C1 Esterase Inhibitor (Conestat alfa) for prophylaxis to prevent attacks in adult and adolescent patients with hereditary angioedema
}

\begin{tabular}{|r|l|}
\hline Journal: & Expert Review of Clinical Immunology \\
\hline Manuscript ID & ERM-2018-0059.R1 \\
\hline Manuscript Type: & Drug profiles \\
\hline Keywords: & $\begin{array}{l}\text { C1-inhibitor, C1-inhibitor deficiency, conestat alfa, hereditary angioedema, } \\
\text { recombinant C1 inhibitor, long-term prophylactic treatment, glycosylation, } \\
\text { serpin, prophylaxis, rhC1-INH }\end{array}$ \\
\hline
\end{tabular}

\section{SCHOLARONE ${ }^{\text {m }}$ \\ Manuscripts}


Title:

\section{Recombinant Human C1 Esterase Inhibitor (Conestat alfa) for prophylaxis to prevent attacks in adult and adolescent patients with hereditary angioedema}




\begin{abstract}
:
Introduction: Hereditary angioedema (HAE) due to $\mathrm{C} 1$ inhibitor (C1-INH) deficiency is a debilitating and potentially lethal disease. Management includes on-demand treatment of angioedema and their prophylaxis. Plasma derived $\mathrm{C} 1-\mathrm{INH}$ is an established treatment for both on demand and prophylaxis of HAE. Conestat alfa is a recombinant form of human $\mathrm{C} 1-\mathrm{INH}(\mathrm{rhC} 1-\mathrm{INH})$ produced in transgenic rabbits. It has granted drug's registration as treatment option for acute HAE attacks in adults and adolescents in Europe, America, and other countries. Long-term prophylaxis with rhC1-INH received recent consideration in clinical trials.
\end{abstract}

Areas covered: This review will critically appraise available information about rhC1INH (conestat alfa) prophylactic treatment in adult and adolescent patients with congenital C1-INH deficiency. Results from a phase II randomized placebocontrolled trial for prophylaxis of severe HAE evidenced positive treatment outcomes for its application, both twice or once weekly.

Expert commentary: Phase II clinical studies suggest that rhC1-INH is a viable option for prophylaxis of HAE. Safety and tolerability data are comparable to other available HAE specific drugs, zeroing the possibility for blood-born viral transmission. Sustainability of modern technologies is granting a practically stable and continuous recombinant production process. With other available options, rhC1-INH facilitates tailoring HAE treatment to patients' needs. 


\section{Introduction and overview of the market}

Hereditary angioedema due to $\mathrm{C} 1$ inhibitor deficiency, hereafter HAE, is an autosomal dominant genetic disease characterized by recurrent attacks of subcutaneous and submucosal swellings. The pathophysiological mechanism involves activation of the contact system and release of the vasoactive peptide bradykinin that increases vascular permeability [1-3] (Figure 1). The underlying genetic defect is in SERPING1 gene that codes for $\mathrm{C} 1$-INH protein. Mutations in one of the two alleles result in low plasma concentration of C1-INH (HAE Type 1), or in low functional plasma levels, due secretion of an antigenically identical dysfunctional protein product (HAE Type 2). Both types have identical impact on the enzymatic systems controlled by $\mathrm{C} 1-\mathrm{INH}$ and cause identical clinical phenotypes [4]. Mutations reported to be pathogenic for $\mathrm{HAE}$ are affecting the C-terminal of the $\mathrm{C} 1$ inhibitor molecule [5], and only one missense mutation in the $\mathrm{N}$-terminal can be related to clinical symptoms of angioedema [6].

HAE manifestations can affect different locations: facial and peripheral subcutaneous angioedema attacks which are disabling, disfiguring and painful; and abdominal mucosal swellings which cause severe pain, and could mimic an emergency surgical condition, 'acute abdomen', possibly resulting in unnecessary invasive iatrogenic procedures $[7][8,9]$. The most serious disease manifestations are the laryngeal attacks, which can lead to death by asphyxiation and are the primary cause for the high mortality rate associated with the disease [10].

Current HAE treatment strategies include 1) on demand therapy (ODT) to revert acute manifestations, 2) long-term prophylaxis (LTP) to avoid/reduce angioedema recurrences and 3) short-term prophylaxis (STP) for attack prevention in high risk 
circumstances [11]. Upon diagnosis and lifelong thereafter, all HAE patients should be enabled to immediate use of ODT at appearance of angioedema, to avoid disease mortality and to shorten attack duration. When this approach does not lead to satisfactory disease control, LTP should be considered to restore normal activities and improve patients' quality of life (QoL) [11].

Several drugs have specific approval for HAE treatment, although with country differences in indication and availability. Plasma derived C1-INHs have indications for both ODT and LTP $[12,13]$. The bradykinin receptor antagonist icatibant, the kallikrein inhibitor kalbitor and the recombinant $\mathrm{C} 1-\mathrm{INH}$ conestat alfa are approved just for ODT $[14,15]$. On the opposite, attenuated androgens are exclusively approved for LTP [16]. In several countries, fresh frozen plasma is the only resource for ODT. Where multiple options are available, choosing among treatments for ODT mainly rely on patient's preferences based on administration route (intravenous or subcutaneous) and perceived efficacy. In LTP, benefits expected from a therapy should receive careful evaluation against side effects: this is particularly difficult when long-term side effects need to be envisaged from drug characteristics in absence of epidemiological evidence.

For decades, cost/benefit balance has been the dilemma of attenuated androgens. Their high clinical efficacy in preventing HAE symptoms, needs to be weight against a long list of potential side effects in absence of studies confirming any treatmentrelated increased morbidity [17]. Ten years ago intravenous pdC1-INH was approved for LTP. A subcutaneous formulation of pdC1-INH was approved for LPT in U.S. in 2017 and will soon reach Europe [18]. The same route of administration is used by lanadelumab, a monoclonal antibody blocking kallikrein for several weeks. This compound successfully completed phase III and is now filing for approval in LTP 
[19]. Again targeted to kallikrein is an oral small molecule that is now entering phase III trial [20]. It is likely that safety shown in other genetic disorders will render gene therapy an appealing approach to completely revert HAE [21].

Considering the large array of effective treatments, we can see LTP approach to HAE aimed at identifying the most physiological and safe drug. Reverting HAE patients to normal clinical and biochemical phenotype is the objective of $\mathrm{C} 1-\mathrm{INH}$ replacing approaches. It has been first attempted using the plasma-derived protein. Therapies based on plasma-derived proteins started in the seventies when main problem were purity and blood borne infections [22]. These problems were minimized over the years and pdC1-INH preparations are highly purified with an excellent safety profile. Both viral safety and purity are guaranteed by accurate monitoring and a purification process abating different infectious agents and leading to final product close to $100 \%$ purity [23-25]. The clinical experience with the pdC1INH available at present shows no report of infection and high clinical efficacy for both ODT and LTP suggesting that the purification process does not affect protein pharmacodynamics [26]. In the second half of 2017 a shortage in availability of pdC1-INH was faced worldwide, due to difficulties to rapidly scale production based on request. This is a well-known problem of plasma based products. As a solution to this, and other above mentioned problems with plasma derived products, recombinant proteins as human therapy became an interesting alternative [27]. The same applies to $\mathrm{C} 1-\mathrm{INH}$, with the recombinant product (rhC1-INH) conestat alfa, currently available as a marketed pharmaceutical product for treatment on HAE. It is produced in the mammary gland cells and secreted into the milk of transgenic rabbits and then purified for use in humans [28].

Efficacy and safety of rhC1-INH for ODT in HAE patients, have been investigated in 
several randomized placebo-controlled trials, as well as in open-label studies [15,2932]. Conestat alfa (Ruconest ${ }^{\circledR}$ ) is currently approved for acute HAE treatment in Europe, the US, Israel and South Korea. The product is available on a namedpatient basis in other territories where it has not yet obtained marketing authorization. Recently, rhC1-INH has shown to be efficacious and well tolerated as a prophylaxis option in a randomized, placebo-controlled crossover trial [33]. The results of this study supported the initial proof of concept open-label prophylaxis study [34], and sporadic case reports of efficacy in LTP and STP [35].

In this publication we will critically review the up-to-date available literature, and also try to address the missing points in current knowledge to explain how rhC1-INH is efficacious as a treatment for prophylaxis of HAE.

\section{Body of review}

\subsection{Why recombinant human $\mathrm{C} 1$-INH from transgenic rabbits?}

We already pointed to the relevance for safe and effective treatment to reverse effects of HAE on patients' life. Knowledge, awareness and existing treatments improved dramatically over the past decades and we are now moving toward HAE personalized therapy.

Human $\mathrm{C} 1$ inhibitor (hC1-INH) is a pluripotent plasma glycoprotein with a vast number of biologic effects and a possibly growing number of therapeutic applications [36]. Considering the large spectrum of physiologic functions, it seems reductive to consider genetic $\mathrm{C} 1-\mathrm{INH}$ deficiency just as a condition exposing to angioedema recurrences and limit therapeutic intervention to avoid this symptom. Accordingly, reversal of the genetic deficiency appears as the approach closest to restore physiologic homeostasis. Recombinant approaches for production of C1-INH started 
in late 1980s aimed at understanding structure-function correlates of disease causing mutations $[37,38]$. Recombinant human $\mathrm{C} 1-\mathrm{INH}(\mathrm{rhC} 1-\mathrm{INH})$ has been produced from mammalian cell culture, bacterial and yeast-based expression systems to be used for research, but these systems were never applied to products for use in humans [39]. This may be explained by rhC1-INH poor expression levels in the culture, its inactivation throughout the production process, and/or the nonmammalian glycosylation profiles of these methods. The expression of rhC1-INH in the milk of lactating transgenic animals provides an alternative to the initially investigated culture-based expression systems. It provides high rhC1-INH expression levels (up to $12 \mathrm{~g} / \mathrm{l}$ ) and mammalian glycosylation profiles as reported for different human proteins $[40,41]$. The rabbit as a transgenic platform gives some specific advantages as relatively short gestation period and safe environment to minimize adventitious agents in the production process. Translated into therapeutic product, these characteristics predict infectious safety and production easily sized to demand. In terms of biologic characteristics, conestat alfa has protease inhibitory properties identical to those of the human plasma protein and significant pharmacokinetic differences likely depending on species specific peculiarities in glycosylation [42]. We aim at discussing further in detail these aspects. (Table 1)

\subsection{Introduction to the drug}

Conestat alpha is a rhC1-INH (Ruconest ${ }^{\circledR}$, Pharming Technologies B.V., Leiden, The Netherlands) obtained through a purification process of transgenic New Zealand white rabbits' milk (Oryctolagus cuniculus). The promoter used to drive expression of the hC1-INH transgene is the bovine alpha-S1-casein promoter, which is specific for the secretion of caseins in the milk. The protein content of rabbit milk is approximately $14 \%$ of which about $65 \%$ consists of various caseins aggregated in 
micelles. The remaining proteins in rabbit milk are whey proteins including transferrin, whey acidic protein, immunoglobulins, albumin and lactalbumin. After collection, rabbit milk undergoes series of standard centrifugation, filtration, and chromatography steps that give rhC1-INH, 99\% purity as assessed by sodium dodecyl sulfate polyacrylamide gel electrophoresis [43]. The $1 \%$ impurities are multimers and $\mathrm{N}$-terminal cleaved $\mathrm{C} 1-\mathrm{INH}$ species. Host-related impurities were analysed (ELISA) and measured to be approximately $10 \mathrm{ppm}$ in the commercial batches and defined to consist of minimal traces of rabbit protein. [43]. The activity of purified rhC1-INH is $6.1 \mathrm{U}$ per $\mathrm{mg}$ of protein, the same as pdC1-INH [43]. Protein sequencing analysis of recombinant and plasma proteins reveals identical polypeptide $\mathrm{N}$ - and $\mathrm{C}$-terminals for the two molecules. Nevertheless, the two proteins differ in molecular mass and this is explained by differences in glycosylation $(21 \%$ and $26-28 \%$ carbohydrate content respectively) $[43,44]$.

Conestat alfa and pdC1-INH showed kinetics for inhibition of C1s, kallikrein, FXIla, and FXla comparable in terms of protein potency and specificity. Observed differences in the various studies can be explained by the different methods used for the experiments, and the differences of the protocol followed for sample collection by the investigators. [25,42,43]. (Table 1)

\subsection{Chemistry and biology: SERPIN vs. Non-SERPIN part of C1-INH}

Sequence analysis demonstrates that the $\mathrm{C} 1$ inhibitor is a member of serin protease inhibitors (serpin) superfamily. The molecule consists of two distinct domains that may be observed by electron microscopy [45]. The serpin domain extends from the carboxy-terminal, contains the reactive site and is responsible for protease inhibitory function. A rod-like amino-terminal of about 100 aa represents the non-serpin 
domain. It shows no significant homology with any known protein and its amino acids' most striking characteristic is the presence of 10 glycosylation sites [46].

As for other serpins, $\mathrm{C} 1-\mathrm{INH}$ consists of alpha-helices and beta-sheets, as well as an exposed mobile reactive center loop that is cleaved upon contact with a target protease [47]. This reaction results in the formation of a stable, covalent bond. Protease binding causes dramatic conformational changes in $\mathrm{C} 1-\mathrm{INH}$, which crushes the protease against its lower pole resulting in irreversible inactivation of the enzyme. This defines serpins to be "suicidal" protease inhibitors. (Figure 2)

C1-INH inactivates a variety of proteases including complement system proteases (C1r, C1s, MASP2), contact system proteases (factor XII, plasma kallikrein), an intrinsic coagulation protease (factor $\mathrm{XI}$ ) and the fibrinolytic proteases (plasmin). (Figure 1) (For detailed review see Davis) [48].

The highly mobile N-terminal of the protein is comprised of 97 amino-acids, and the attached sugars probably being of greater biologic importance than its non-compact polypeptide chain. This $\mathrm{N}$-terminal, elongated domain, probably plays the role of an "anchor", helping the C1-INH molecule to "attach" to different surfaces. It does not directly contribute to protease inhibition and establishes non-covalent interactions with other proteins, and cell surfaces or lipids [36,49,50].

Differences in the N-terminal glycosylation (see Table 1) modify the pharmacokinetics of the molecule. The removal of sialic acids from C1-INH (asialo$\mathrm{C} 1-\mathrm{INH})$ is found to significantly enhance its clearance from the circulation showing a half-life of 3 to $5 \mathrm{~min}$ in an investigational rabbit model [51]. This effect is presumably conducted via its binding to asialo-glycoprotein receptors in the liver with enhanced clearance due to exposure of the penultimate galactosyl residue. Subsequent 
removal of the latter reverts the clearance rate up to values similar to that of normal C1-INH [51]. Though, the removal of sialic acid or galactose groups does not impair the protease inhibitory function of $\mathrm{C} 1-\mathrm{INH}$ in vitro [51].

As expected, rhC1-INH produced in transgenic rabbits differs from $\mathrm{C} 1-\mathrm{INH}$ produced in humans in the glycosylation profile. In fact, each animal adds sugar-to-protein with a pattern specific of the species, and furthermore, differences might occur between different tissues within the same species.

\section{a. Pharmacodynamics}

Genetically low $\mathrm{C} 1-\mathrm{INH}$ function, lessens the control of the esterase activity that generates upon spontaneous formation of the $\mathrm{C} 1$ complex. Such an inefficient control allows cleavage of the natural substrates of $\mathrm{C} 1, \mathrm{C} 4$. In HAE patients, neosynthesis of $\mathrm{C} 4$ cannot compensate consumption resulting in characteristically low plasma levels. Reversal of C4 consumption with normalization of plasma levels has been used as biomarker for therapies target to $\mathrm{C} 1-\mathrm{INH}$ replacement. Accordingly, pharmacokinetic curve of conestat alfa at doses of 100 and $50 \mathrm{U} / \mathrm{Kg}$, shows a dosedependent restoration of C4 consumption measured by decrease of $\mathrm{C} 4$ break-down products (C4b/c) and parallel increase of C4 plasma levels [42]. C4 peaks approximately 12 hours post-infusion and then gradually reverts to baseline levels. When post-infusion $\mathrm{C} 1-\mathrm{INH}$ functional plasma fall below $0.7 \mathrm{U} / \mathrm{ml}, \mathrm{C} 4$ consumption resumes. Doses below $25 \mathrm{U} / \mathrm{kg}$ have minimal effect on C4 plasma levels.

Pharmacodynamics effect of rhC1-INH is measured as reduction in the amount of cleaved high-molecular-weight kininogen (cHK), indirect marker of bradykinin formation. Cleaved HK increases during attacks in HAE and in inter-critical periods discriminates frequently symptomatic patients from those suffering rare angioedema 
symptoms [52]. Conestat alfa in doses of $50 \mathrm{U} / \mathrm{Kg}$ significantly reduces $\mathrm{cHK}$ [53].

\section{b. Pharmacokinetics and metabolism of rhC1-INH}

Plasma levels of $\mathrm{C} 1-\mathrm{INH}$ in the normal population range from 70 to $130 \%(0.7-1.3$ $\mathrm{U} / \mathrm{ml}$ ). In a large HAE population, functional levels of $\mathrm{C} 1-\mathrm{INH}$ ranged between $10 \%$ and $30 \%$ [54]. In the open-label escalation study with conestat alfa in asymptomatic HAE patients (doses from 6.25-100 $\mathrm{U} / \mathrm{kg}$ ) there is a dose-dependent increase in functional C1-INH activity up to normal for doses of 50 and $100 \mathrm{U} / \mathrm{kg}$ [42]. Elimination half-life derived from this study is 1.6 and $2 \mathrm{hrs}$, which is clearly shorter compared to plasma C1-INH. The fractional catabolic rate of radiolabelled $\mathrm{C} 1-\mathrm{INH}$ purified from normal plasma, is 0.025 of the plasma pool/hour in normal subjects and 0.035 in HAE patients [55]. These catabolic rates correspond to a half-life 20 and 14 hours respectively. When pdC1-INH for therapeutic use substitutes the radiolabelled protein, the estimated post-infusion half-life shows great variability among studies. Using Berinert, it is $39.1 \mathrm{hrs}$, with Cinryze $56 \mathrm{hrs}[12,56]$. The conditions of these studies are extremely different and head to head comparison among preparations is not appropriate. Nevertheless, the strikingly shorter half-life of the recombinant protein is evident. It is explained by the glycosylation profile of the recombinant product that enhances binding to asyaloglycoprotein and mannose receptors that are abundant in the liver and rapidly clear the protein from the circulation. The dosedependent increase of the half-life of rhC1-INH is ascribed to saturation of these receptors [42]. However, the clinical efficacy of conestat alfa does not appear to be affected by the shorter plasma life. A meta-analysis of controlled studies of efficacy of on demand pdC1-INH and rhC1-INH, shows a dose dependent increase, which is independent from the pharmacokinetic characteristics of the different products [57]. A model of population pharmacokinetic (PPK) analysis used data from 120 subjects 
who received 214 administrations of rhC1-INH during 6 clinical studies [58]. Using the Michaelis-Menten elimination kinetics model, a single dose of rhC1-INH of 50 $\mathrm{U} / \mathrm{kg}$ would restore normal functional C1-INH levels in more than $94 \%$ of C1-INHHAE patients. This suggests that doses below $50 \mathrm{U} / \mathrm{Kg}$ prevent a vast number of the patients from achieving C1-INH levels within the normal range [57]. The PPK model confirms the importance of a weight-based dosing of rhC1-INH up to a dose of 4200 U (two commercial vials). The PPK model was also used to investigate differences in peak $\mathrm{C} 1-\mathrm{INH}$ activity levels after initial administration compared to repeated administrations for subsequent HAE attacks, and indicated no such differences [58].

\section{d) Clinical development of conestat alfa}

\section{Phase I studies - an open-label dose-escalation study}

The study protocol for this open-label dose-escalation study was conducted in 12 asymptomatic subjects with a typical medical history of HAE with functional C1-INH and C4 levels of less than $40 \%$ of normal. All subjects were symptom free for a period of at least 2 weeks before rhC1-INH was administered for the purpose of the study. The patients were divided into 4 groups of 3 patients (starting from 6.25, 12.5, 25 , and $50 \mathrm{U} / \mathrm{kg}$, respectively) and each patient was given 2 doses of rhC1-INH with a washout period of at least 5 weeks before the dose was escalated up to $100 \mathrm{U} / \mathrm{kg}$. The course of functional $\mathrm{C} 1-\mathrm{INH}$ in plasma showed a full initial recovery and a dosedependent clearance of rhC1-INH. The observed safety profile and biologic activity of rhC1-INH suggested further clinical studies to assess its efficacy in treating acute HAE attacks [42].

\section{On demand treatment of acute attacks}

The efficacy of rhC1-INH for the treatment of HAE patients during acute angioedema 
attacks has been demonstrated in several studies, including three double-blind, placebo-controlled efficacy studies [15,29] and five open-label studies where patients maintained treatment of subsequent attacks [29,30,32,34,59]. No relapse or rebound episodes were reported, suggesting that conestat alfa mechanism of action and specific pharmacodynamics, lead to sustained protein activity, rather than its relatively short elimination plasma half-life. In the largest of these studies $(n=224$ attacks treated), $96 \%$ of attacks were treated with a single dose of rhC1-INH of 50 $\mathrm{U} / \mathrm{kg}(\max 4200 \mathrm{U})$ [30]. Moreover, administration of an additional treatment dose was not reported for subsequent attacks.

\section{Prophylaxis}

The efficacy of rhC1-INH for prophylactic treatment of patients with HAE to prevent onset of angioedema attacks has been investigated in two studies, one open label pilot study and one double-blind, randomized, placebo-controlled study [33,34]. Extension for the indication has been submitted and waiting for approval, expected in the third quarter of 2018 [60].

\section{Open-label pilot prophylaxis study in HAE}

An open-label, uncontrolled, pilot study to test efficacy and safety of prophylactic once-weekly administration of conestat alfa at $50 \mathrm{U} / \mathrm{kg}$ was conducted over an 8weeks period in patients with high frequency of monthly attacks [34]. The study enrolled 25 patients with a mean attack-rate of 0.9 attacks per week (median of 0.6 attacks, range 0.4 to 4.5 attacks per week). The mean breakthrough attack rate during the treatment period was 0.4 attacks per week (median of 0.3 , range from 0.0 to 1.5 attacks per week), which showed to be significantly lower than the reported historical average attack rate. 


\section{Randomized placebo-controlled trial for prophylaxis of HAE}

Recently, the results from a phase II multi-centre, randomized, double-blind, placebo-controlled, 3-period cross-over study were published [33]. The study aimed at evaluating the efficacy and safety of conestat alfa in prophylaxis of angioedema attacks within adult and adolescent patients with severe course of C1-INH-HAE. Eligible patients were those above the age of 13 years with a clinical history of frequent HAE attacks (>4 attacks per month). Each patient received three 4-week periods of treatment, twice weekly, with a 1-week washout between different treatment periods. The study was conducted in 32 (ITT) patients (26 completed the study) who received intravenously in a double-blind fashion injection of conestat alfa $50 \mathrm{U} / \mathrm{kg}$ (to a maximum of $4200 \mathrm{U}$ for patients $\geq 84 \mathrm{~kg}$ ), either once weekly or twice weekly. The outcomes reported by the authors were that the mean number of attacks of hereditary angioedema over 4 weeks was significantly reduced with conestat alfa twice weekly, and once weekly, versus placebo, with mean differences of $-4 \cdot 4$ attacks $(p<0 \cdot 0001)$ and $-2 \cdot 8$ attacks $(p=0 \cdot 0004)$, respectively [33].

In addition, prophylaxis with conestat alfa for HAE has been reported in sporadic case report series, both used in long-term prophylaxis, and as a successful choice in short-term prophylaxis before deemed invasive procedures [35]. (Table 2)

\section{e) Post marketing surveillance}

The database following safety and tolerability of conestat alfa includes clinical and laboratory data arising from almost 1600 administrations of rhC1-INH in twelve completed clinical development program studies. [53]

\section{Adverse events:}


The safety data analyses demonstrate that rhC1-INH at doses of $50 \mathrm{IU} / \mathrm{kg}$ and 100 $\mathrm{IU} / \mathrm{kg}$ is generally safe and well tolerated when administered for treatment and prevention of HAE attacks. The adverse event profile found in the randomized, placebo-controlled studies was similar for patients treated in the rhC1-INH and saline treatment groups. There was no increase in the incidence of treatment-emergent adverse events with higher rhC1-INH dose, administration of additional rhC1-INH doses for an attack, or with repeated treatment of subsequent attacks [30]. The most common adverse reactions $(\geq 2 \%)$ reported in all clinical trials were headache, nausea and diarrhea.

Important for clinical practice is to avoid using the product in patients who are rabbit allergic due to potentially serious allergic reactions, which has happened within three minutes after administration of conestat alfa in only a single healthy volunteer with a pre-existent (retrospectively known), non-disclosed rabbit dander allergy [42]. Throughout the clinical development of the drug, no safety issue related to hematology, biochemistry, coagulation, urinalysis, vital signs, or ECG parameters was noted.

\section{Thrombogenicity:}

Concerns regarding a thrombogenic risk of conestat alfa, or regarding a clinically meaningful effect on activation of coagulation or fibrinolysis (due to its effect on proteases of the contact/coagulation system and previous reports in high-dose treatment with plasma-derived $\mathrm{C} 1-\mathrm{INH}$ ) have not been recorded during clinical development and clinical studies. Conestat alfa did not show effect on activation of coagulation and fibrinolysis [61]. In fact, D-dimer levels, which are considered biomarkers of thrombosis were followed during acute treatment with conestat alfa 
and treatment was not associated with thrombotic events [62].

\section{Immunogenicity:}

Immunogenicity of rhC1-INH was extensively tested throughout the clinical development programs, supporting that conestat alfa has low potential to induce anti-C1-INH antibodies or anti-host-related impurities (HRI) response.

Confirmed antibodies against C1-INH or HRI were observed infrequently and were not associated with clinical symptoms indicating hypersensitivity or changes in rhC1INH efficacy [63].

There was no association between treatment-emergent adverse events or new acute HAE attacks and the presence of any confirmed anti-C1-INH or anti-HRI antibodies. No patients were tested positive for neutralizing antibodies to endogenous $\mathrm{C} 1-\mathrm{INH}$ or rhC1-INH. No anti-rabbit IgE antibodies were reported elevated with treatment with conestat alfa and moreover, no severe hypersensitivity reactions were reported beyond the single case in a Phase 1 study and in the post-approval phase as of the date of the manuscript preparation. (Table 3)

\section{f) Regulatory affairs}

RhC1-INH started to be investigated as a potential pharmacological agent in the treatment in HAE with various clinical studies conducted since the late 1980s

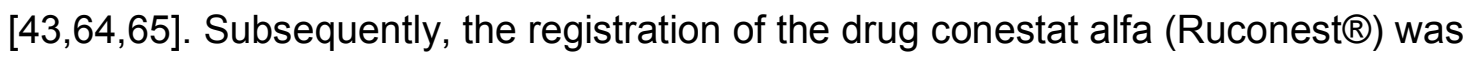
secured in 2010 in Europe, and following in 2014 in the USA and Israel.

The European Commission has granted rhC1-INH (Ruconest $\circledast$ ) a marketing authorization for the treatment of acute angioedema attacks in adults and 
adolescents with HAE due to C1-INH deficiency. Currently, it is now approved for use in all the $28 \mathrm{EU}$ member countries plus Norway, Iceland and Liechtenstein.

The United States' Food and Drug Administration (FDA) approved rhC1-INH

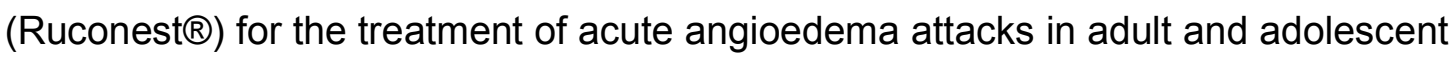
patients with C1-INH-HAE. Because of the limited number of patients with laryngeal attacks, effectiveness was not established in HAE patients with laryngeal attacks by the FDA.

Conestat alfa is approved in Israel for the treatment of acute angioedema attacks in adults with hereditary angioedema (HAE) due to $\mathrm{C} 1$ esterase inhibitor deficiency. Conestat alfa is approved in South Korea for the treatment of acute angioedema attacks, except oro-pharyngeal \& laryngeal locations in adult patients with hereditary angioedema.

In the pediatric population (2-13 years old), the study has been completed and submitted for approval, awaiting to expand the indication in this subpopulation (https://www.pharming.com/pharming-announces-positive-data-from-paediatricclinical-trial-with-ruconest/).

\section{Conclusion}

Hereditary angioedema (HAE) is a rare autosomal dominant disease characterized by recurrent swellings of the extremities, oro-facial-pharyngeal zones, upper airways, genitalia, often severely disrupting patients' lives. HAE is a potentially life threatening disease, with $1-5 \%$ of all angioedema episodes locate to the larynx. In absence of appropriate diagnosis and treatment $25 \%$ of patients die for laryngeal edema [10]. The burden of HAE has huge geographical discrepancy due to differences in treatment availability. In the recent years, new drugs for $\mathrm{C} 1-\mathrm{INH}-\mathrm{HAE}$ were approved in Europe and North America. Available treatments can be seen as optimal to avoid 
mortality granted unrestricted availability and education for appropriate use. In terms of minimizing morbidity, on demand approach is insufficient for frequently symptomatic patients; attenuated androgens are limited by side effects and intravenous pdC1-INH by administration route and empiric optimal dosing. Raising demand for optimal prophylaxis, pushed towards development of novel hi-technology approaches based on different platforms. Subcutaneous pdC1-INH, already available in U.S., and upcoming prophylactic approaches tackling plasma kallikrein, should further improve treatment efficacy and customization. Using transgenic animal technology, rhC1-INH aims at providing replacement therapy with a human protein produced by recombinant technology that is free from blood borne human infectious agents and in transgenic animal that allows to scale production based upon request. The recently published phase II study demonstrates that the short half-life of the rhC1-INH does not lessen efficacy as prophylactic therapy. Safety, tolerability and efficacy on repeated infusions, relay on the long development program that brought rhC1-INH registration in Europe, USA, Israel, and other countries for treatment of acute HAE attacks in adult and adolescent patients. The same intravenous formulation was used to obtain evidence for effective in prophylaxis. In the presence of subcutaneous and oral competitors prophylactic therapy administered intravenously, cannot be successful. A concentrated formulation of conestat alfa for subcutaneous or intramuscular administration is expected to bring this product into the market for HAE prophyalxis. When such a low-volume formulation will prove as effective as competitors in large number of patients followed for several months, the compound will become an interesting additional alternative for patients with HAE.

\section{Expert commentary}


$\mathrm{C} 1-\mathrm{INH}$ is an acute-phase protein that for structure and inhibitory mechanism belongs to the superfamily of serine-protease inhibitors. Soon after discovery that genetic $\mathrm{C} 1-\mathrm{INH}$ deficiency was the cause of HAE, C1-INH derived from human plasma became the life-saving drug for these patients. Technological evolution and improved safety expanded the indication of plasma derived products are now used as replacement therapy in genetic defects. This is true also for $\mathrm{C} 1-\mathrm{INH}$, established treatment for long-term prophylaxis of HAE. Need for large supply of safe proteins, prompted to develop the recombinant technology in transgenic animals. Conestat alfa, the recombinant human $\mathrm{C} 1-\mathrm{INH}$ purified from milk of transgenic rabbits, was initially approved as on demand intravenous therapy. When long-term replacement of C1-INH deficiency by the plasma derived protein became a standard approach to the disease, conestat alfa was considered for analogous use. Main drawback to foresee this product as successful for prophylaxis was its short half-life. Six hours after infusion conestat alfa is not detectable in patients' plasma. Nevertheless, analysis of data from on demand trials showed that clinical efficacy of plasma and recombinant $\mathrm{C} 1-\mathrm{INH}$ was dependent on the initial dose and not influenced by the pharmacokinetic profile. Moreover, an animal model of stroke, showed rhC1-INH to be superior to the pdC1-INH in protecting from extension of the ischemic brain injury [66]. Such a difference appeared to be explained by the stronger affinity of rhC1-INH for mannan binding lectin (MBL) and thus better inhibit the lectin pathway of complement: rhC1-INH binds $\mathrm{MBL}$ with a relatively high affinity (230nM), whereas pdC1-INH does not show any binding up to 40um [67]. Thus, the possibility that clearance from the circulation did not necessarily mean protein catabolism was considered. Normal C1-INH binds to endothelial cells maintaining intact protease inhibitory activity [68]. C1-INH binding characteristics have been 
investigated to explain other potential anti-inflammatory effects of human $\mathrm{C} 1-\mathrm{INH}$ [49]. These effects do not appear to require protease inhibition and depend on noncovalent interactions with other proteins, cell surfaces or lipids. C1-INH is a multifaceted anti-inflammatory protein that acts through a variety of mechanisms including protease inhibition in addition to several different non-covalent interactions, not related to its anti-protease activity.

Thus, efficacy of conestat alfa, administered once or twice per week, in HAE prophylaxis was tested on the hypothesis that $\mathrm{rhC} 1-\mathrm{INH}$ is still biologically active after disappearance from the circulation. The promising results of the two studies where conestat alfa was tested as prophylactic agent suggest that the hypothesis is valid. In order to become an alternative for replacement therapy in HAE patients, a low-volume subcutaneous or intramuscular formulation of conestat alfa needs to demonstrate to be as effective as the plasma-derived protein.

The possibility that rhC1-INH has biologic activity independent from plasma levels opens to the possibility of indications outside from HAE. Plasma derived C1-INH and rhC1-INH have been studied in a variety of animal models of diseases involving contact and complement system. Among others, pancreatitis, sepsis, thermal injury, xenotransplantation, and various models of ischemia-reperfusion injury (e.g., myocardial infarction, stroke, delayed graft function in transplantation) $[69,70][71,72][73][74][75,76][77]$. The efficacy of C1-INH in humans with these disease states needs to be assessed by appropriate studies. When such studies will be designed the different efficacy of plasma and recombinant products will have to be considered taking into account the findings in the animal model of stroke.

\section{Five-year view}


In a five-year period, we can easily envisage that HAE prophylaxis with androgens will be marginal in countries where new treatments are available. On demand treatment and prophylaxis will still co-exist due to the high variability in symptom frequency. In the field of prophylaxis two approaches will compete: replacing the genetic defect versus silencing the generation of the angioedema mediator. Both appear to provide nearly complete prevention of symptoms and decision will rely on expected long term benefit and patient preference. C1-INH replacement appears more physiologic and some long-term experience is already available to confirm absence of side effects. Theoretical positive aspect for $\mathrm{C} 1-\mathrm{INH}$ is the possibility to prevent, along with angioedema, the consumption of classical pathway complement components. Genetic defects of the components of this pathway are associated with reduced apoptosis and autoimmunity [78]. We still lack data showing whether C1INH deficiency exposes to diseases other than angioedema. In a short, while HAE registries will make this information available facilitating therapies tailored on patients' needs. This is part of a general trend towards personalized/precision medicine aimed at restoring the physiologic state in respect of personal needs. Nontrivial to this is treatment administration modality. In 5 years, we will still have HAE patients controlling the disease with an on demand approach or others with prophylaxis. For the last approach there will be subcutaneously injectable treatments delivered every few days or every month, as well as daily tablets. Choosing between the different options depends mainly on patients' attitude. There are patients who just want to forget the disease and others, who prefer to maintain an active control. The different options will likely satisfy most of these needs. 
To close, we can predict that in 5 years extended information on disease variability and a large array of treatment options will render HAE the prototype of successful precision medicine.

\section{Key issues}

- Hereditary angioedema (HAE) results from an autosomal dominant hereditary deficiency of the plasma protein $\mathrm{C} 1$ inhibitor (C1-INH-HAE) and is characterized by the occurrence of acute attacks of angioedema that can be life-threatening, disfiguring and/or disabling.

- Recombinant human $\mathrm{C} 1-\mathrm{INH}(\mathrm{rhC} 1-\mathrm{INH})$ is approved for the treatment of acute angioedema in adult and adolescent patients with HAE.

- A recent publication from a phase 2 randomized double-blind, placebo controlled, cross-over trial has presented data about rhC1-INH as an efficacious agent for prophylactic treatment of HAE in adult and adolescent patients, which confirms the previously reported data from an open label pilot study and sporadic case reports.

- $\mathrm{C} 1-\mathrm{INH}$ is a human plasma protein involved in the regulation of the complement, coagulation, fibrinolysis, and contact systems. It is a powerful controlling protein in early stages of these bio-amplification cascades, and in that way, a crucial regulating factor of the innate immune response. Therefore, its role could be further investigated as a potential controller agent in various cases of abnormal inflammation.

- Recombinant human $\mathrm{C} 1$ inhibitor (rhC1-INH) has some distinguishing features, when compared to plasma-derived $\mathrm{C} 1-\mathrm{INH}$, probably related to the difference in the glycosylation of the non-serpin $\mathrm{N}$-terminal of the molecule. These specificities account for the differences in its pharmacokinetic 
behaviour (e.g. shorter plasma half-life), as well as its stronger affinity to suppress the lectin complement pathway.

- Further studies are needed to explain rhC1-INH behaviour in the human body, as the drug's plasma half-life of clearance is not a sufficient predictor of its efficacy.

\section{Information resources}

Pubmed: https://www.ncbi.nlm.nih.gov/pubmed/

Clinical trials.gov registry and database of clinical studies of human participants: https://clinicaltrials.gov

Pharma companies' websites: www.ruconest.com, www.cinryze.com, www.berinert.com, www.haegarda.com

Regulatory affairs: www.ema.europa.eu, www.fda.gov 


\section{Legends: Figures and Tables}

\section{Figures:}

1. Figure 1: Bio-amplification plasma cascades and $\mathrm{C} 1-\mathrm{INH}$.

2. Figure 2: C1-INH: mechanism of action with proteases

\section{$\underline{\text { Tables }}$}

3. Table 1: Characteristics of recombinant human and plasma-derived C1-INHs

4. Table 2: Clinical efficacy: studies with rhC1-INH for prophylaxis

5. Table 3. Safety and tolerability of rhC1-INH and competitors for prophylaxis of HAE 
2

3

4

5

6

\section{Table 1: Characteristics of recombinant human and plasma-derived C1-INH}

\begin{tabular}{|c|c|c|}
\hline \multicolumn{3}{|l|}{ Characteristics of C1-INH } \\
\hline Classification & \multicolumn{2}{|l|}{ Serine protease inhibitor, serpin } \\
\hline Synonyms & \multicolumn{2}{|c|}{ C1-esterase inhibitor, C1s-inhibitor, C1-inactivator, alpha2-neuramino-glycoprotein, Serpin Family G member 1} \\
\hline Activity/Function & \multicolumn{2}{|c|}{$\begin{array}{l}\text { C1-inhibitor controls activation of the } \mathrm{C} 1 \text { complex and the generation of kinins. It inhibits the target proteases by } \\
\text { the formation of a proteolytically inactive stoichiometric complex. It regulates proteases in complement, contact, } \\
\text { coagulation and fibrinolytic systems. }\end{array}$} \\
\hline Cofactors & \multicolumn{2}{|l|}{ Glycosaminoglycans } \\
\hline \multicolumn{3}{|c|}{ Characteristics of commercially available C1-INH for the treatment of HAE } \\
\hline Properties & Recombinant human C1 inhibitor (conestat alfa) & Plasma derived $\mathrm{C} 1$ inhibitors \\
\hline Target proteases & \multicolumn{2}{|c|}{ C1s, C1r, aFXIla, bFXIla, kallikrein, FXla, plasmin, MASP-1, MASP-2 } \\
\hline Mature polypeptide sequence & \multicolumn{2}{|c|}{ Identical, 478 amino acids } \\
\hline $\begin{array}{l}\text { Apparent Molecular Weight* kDa } \\
\text { (SDS-PAGE) }\end{array}$ & 98 [25] & $105[25]$ \\
\hline $\begin{array}{l}\text { Molecular Weight** kDa } \\
\text { (mass spectrometric analysis) }\end{array}$ & 67 [43] & 74-71[44] [43] \\
\hline Carbohydrate contents (w/w) & $21 \%[43]$ & $28-26 \%[43,44]$ \\
\hline $\begin{array}{l}\text { Glycosylated amino-acids } \\
\text { (mature protein) }\end{array}$ & Not reported & $\begin{array}{l}\text { Multiple O-linked and } 6 \mathrm{~N} \text {-linked glycans: } \\
\text { Six N-glycosylation sites at Asn-3, }-47,-59,-216 \text {, } \\
-231 \text {, and }-330 \text {. Seven O-glycosylation sites at } \\
\text { Ser-42 and Thr-26, }-49,-61,-66,-70 \text {, and - } \\
74[44] \text {. Another study reported } 24 \text { O-glycosilation } \\
\text { sites [46] }\end{array}$ \\
\hline Type of sugar residues & $\begin{array}{l}\mathrm{N} \text {-glycans of oligomannose-, hybrid-, and complex-type } \\
\text { structures. } 25 \% \text { are neutral and the remaining are } \\
\text { sialylated ( } \mathrm{N} \text {-acetylneuraminic acid only). Of these. } 67 \% \\
\text { are monocharged of the hybrid-, mono- or diantennary } \\
\text { complex type. Part are (a1-6)-core-fucosylated or (a1-3)- } \\
\text { fucosylated in the lower or upper antenna (Lewis x } \\
\text { epitope). Small core 1-type O-glycans with the usual (a2- } \\
\text { 3)- and (a2-6)-sialylation pattern of O-glycoproteins of } \\
\text { nonmucinous origin [28] }\end{array}$ & $\begin{array}{l}\text { ( } \alpha 2-3) \text {-disialylated and }(\alpha 2-6) \text {-disialylated } \\
\text { complex-type diantennary } \mathrm{N} \text {-glycans (molar ratio, } \\
2: 1) .(\alpha 2-3) \text { - monosialylated core } 1 \text {-type O- } \\
\text { glycan. The } \mathrm{N} \text {-glycans are }(\alpha 1-6) \text {-core- } \\
\text { fucosylated for } 30 \% \text {, and the only sialic acid } \\
\text { found is } \mathrm{N} \text {-acetylneuraminic acid. Lower amounts } \\
\text { of sialylated tri- and tetraantennary structures are } \\
\text { also reported [44] }\end{array}$ \\
\hline Plasma half-life of clearance (hours) & $\begin{array}{l}1.6(50 \mathrm{U} / \mathrm{kg})[42] \\
2.9(100 \mathrm{U} / \mathrm{kg})[42]\end{array}$ & 10 - 96 [79-81] \\
\hline Activity (concentration) $\mathrm{U} / \mathrm{mL}$ & $150[25]$ & $50-100[25]$ \\
\hline Genetics & $\begin{array}{l}\text { Human C1-INH gene sequence through a bovine alpha- } \\
\text { S1-casein promoter, specific for the secretion of caseins in } \\
\text { the milk, introduced via micro-injection transgenic } \\
\text { technique in New Zealand white rabbits (Oryctolagus } \\
\text { cuniculus) }\end{array}$ & $\begin{array}{l}\text { 17-kilobase single-copy gene on human } \\
\text { chromosome } 11 \text {, which consists of eight exons }\end{array}$ \\
\hline Synthesis & $\begin{array}{l}\text { New Zealand white rabbits mammary gland epithelial cells } \\
\text { and secreted in the milk }\end{array}$ & $\begin{array}{l}\text { Human hepatocytes, fibroblasts, monocytes, } \\
\text { macrophages, endothelial cells, amnionic } \\
\text { epithelial cells, and perhaps cells in the microglia }\end{array}$ \\
\hline \multicolumn{3}{|l|}{ Final purity of the commercial drug } \\
\hline Purity & $99 \%[25]$ & $89-97 \%[25]$ \\
\hline Impurities & $\begin{array}{l}1 \% \text { rhC1-INH multimers and } \mathrm{N} \text {-terminal cleaved } \mathrm{C} 1-\mathrm{INH} \\
\text { species }[25,43]\end{array}$ & $\begin{array}{l}3-11 \% \text { low and high-molecular weight proteins } \\
\text { [25] }\end{array}$ \\
\hline Host related impurities & $\begin{array}{l}10 \mathrm{ppm}, \text { traces of rabbit protein; } \\
\text { No endogenous rabbit C1-INH [25] }\end{array}$ & $\begin{array}{l}\text { Human a1-antichymotrypsin and ceruloplasmin, } \\
\text { C3, immunoglobulin heavy constant mu [25] }\end{array}$ \\
\hline \multicolumn{3}{|c|}{$\begin{array}{l}\text { Kinetics, second-order rate constant } \boldsymbol{K}_{\text {on }}\left(\boldsymbol{M}^{-1} \boldsymbol{s}^{-1}\right) \\
\text { (higher values correspond to higher inhibitory capacity) }\end{array}$} \\
\hline $\mathrm{C} 1 \mathrm{~s}$ & $6.1 \times 10 \times 4[43]$ & $\begin{array}{l}5.1 \times 10 \times 4[43] \\
4.8 \times 10 \times 4[64] \\
6.2 \times 10 \times 4[39]\end{array}$ \\
\hline Factor Xla & $9.8 \times 10 \times 2[43]$ & $\begin{array}{l}9.0 \times 10 \times 2[43] \\
1.8 \times 10 \times 3[82] \\
3.9 \times 10 \times 2[39]\end{array}$ \\
\hline Factor XIla & $6.9 \times 10 \times 3[43]$ & $\begin{array}{l}5.7 \times 10 \times 3[43] \\
9 \times 10 \times 3[82] \\
4.5 \times 10 \times 3[39]\end{array}$ \\
\hline Kallikrein & $9.1 \times 10 \times 3[43]$ & $\begin{array}{l}7.6 \times 10 \times 3[43] \\
2.6 \times 10 \times 4[82] \\
7.8 \times 10 \times 3[39]\end{array}$ \\
\hline
\end{tabular}


Legend: C1-INH, C1 esterase inhibitor; rhC1-INH, recombinant human C1 inhibitor; pdC1INH, plasma-derived C1 inhibitor; GAGs, glycosaminoglycans, HAE, hereditary angioedema; C1s, complement C1s; C1r, complement C1r; FXII, factor XII; FXI, factor XI; MASP1/2, mannan-binding lectin serine protease 1/2; C-terminal, protein carboxyl-terminus; $\mathrm{N}$ terminal, protein amino-terminus; C3, complement C3.

* Measured by Sodium Dodecyl-Sulfate polyacrylamide gel electrophoresis

** Measured by fine neutron scattering 
Table 2: Clinical efficacy: studies with rhC1-INH for prophylaxis

\begin{tabular}{|c|c|c|c|c|c|}
\hline $\begin{array}{l}\text { Study } \\
\text { Number }\end{array}$ & Phase of study & Subjects & Therapeutic regimen & Results & Reference \\
\hline NCT00851409 & $\begin{array}{l}\text { Pilot phase II open- } \\
\text { label prophylaxis } \\
\text { study }\end{array}$ & $\begin{array}{l}\text { Adult C1-INH-HAE } \\
\text { patients with } \\
\text { history of at least } 2 \\
\text { attacks/month } \\
\mathrm{N}=25 \text { (ITT) }\end{array}$ & $\begin{array}{l}\text { Weekly administration } \\
\text { of } 50 \mathrm{U} / \mathrm{kg} \text { conestat } \\
\text { alfa }\end{array}$ & $\begin{array}{l}\text { Mean weekly attack rate } \\
\text { decreased during the } \\
\text { study to } 0.4 \\
\text { attacks/week, as } \\
\text { compared with the pre- } \\
\text { study attack-per-week } \\
\text { rate of } 0.9\end{array}$ & [34] \\
\hline NCT02247739 & $\begin{array}{l}\text { Phase II multicenter, } \\
\text { randomized, double- } \\
\text { blind, placebo- } \\
\text { controlled, 3-period } \\
\text { cross-over study }\end{array}$ & $\begin{array}{l}\geq 13 \text { years older } \\
\mathrm{C} 1-\mathrm{INH}-\mathrm{HAE} \\
\text { patients with } \\
\text { history of at least } 4 \\
\text { attacks/monthly in } \\
\text { the last } 3 \text { months } \\
\text { prior to study } \\
\text { enrollment } \\
\mathrm{N}=32 \text { (ITT) }\end{array}$ & $\begin{array}{l}\text { Three 4-week-periods } \\
\text { of intravenous } \\
\text { injection of conestat } \\
\text { alfa } 50 \mathrm{U} / \mathrm{kg} \text { (to a } \\
\text { maximum of } 4200 \mathrm{U} \\
\text { for patients } \geq 84 \mathrm{~kg} \text { ), } \\
\text { either once or twice } \\
\text { weekly with a } 1 \text {-week } \\
\text { washout between } \\
\text { treatment periods }\end{array}$ & $\begin{array}{l}\text { The number of attacks } \\
\text { of hereditary } \\
\text { angioedema over } 4 \\
\text { weeks was significantly } \\
\text { reduced with conestat } \\
\text { alfa twice weekly, and } \\
\text { once weekly, versus } \\
\text { placebo, mean } \\
\text { differences of }-4 \cdot 4 \\
\text { attacks }(p<0 \cdot 0001) \text { and } \\
-2 \cdot 8 \text { attacks }(p=0.0004) \text {, } \\
\text { respectively }\end{array}$ & [33] \\
\hline
\end{tabular}

C1-INH-HAE, hereditary angioedema due to C1 inhibitor deficiency; 
Table 3. Safety and tolerability of rhC1-INH and competitors for prophylaxis of HAE

\begin{tabular}{|c|c|c|c|c|c|}
\hline Drug (molecule) & $\begin{array}{l}\text { Commercial } \\
\text { name, Company }\end{array}$ & $\begin{array}{l}\text { Subjects and therapeutic } \\
\text { regimen }\end{array}$ & Adverse events & $\begin{array}{l}\text { Warnings and } \\
\text { precautions }\end{array}$ & References \\
\hline \multirow[t]{2}{*}{ rhC1-INH } & \multirow[t]{2}{*}{$\begin{array}{l}\text { Ruconest, } \\
\text { Pharming B.V. }\end{array}$} & \multirow{2}{*}{$\begin{array}{l}\text { Adults and adolescents; } \\
50 \mathrm{IU} / \mathrm{kg} \text {, twice weekly, I.V. } \\
\text { (up to } 4200 \mathrm{IU} \text { for } \geq 84 \mathrm{~kg} \text { ) }\end{array}$} & \multirow[t]{2}{*}{$\begin{array}{l}\text { Headache, nausea } \\
\text { and diarrhea }\end{array}$} & $\begin{array}{l}\text { Potentially serious allergic } \\
\text { reactions in rabbit allergic } \\
\text { patients. }\end{array}$ & $\begin{array}{l}{[15,29-} \\
31,34,42,55,63,83,84]\end{array}$ \\
\hline & & & & Potential immunogenicity. & SPC of the product \\
\hline \multirow[t]{3}{*}{ pdC1-INH } & \multirow[t]{3}{*}{$\begin{array}{l}\text { Cinryze, } \\
\text { Shire }\end{array}$} & \multirow{3}{*}{$\begin{array}{l}\text { Adults and adolescents; } \\
1000 \mathrm{IU} \text {, twice weekly, I.V. } \\
\text { (up to } 2500 \mathrm{IU} \text {, but no more } \\
\text { than } 100 \mathrm{IU} / \mathrm{kg} \text { ) }\end{array}$} & \multirow{3}{*}{$\begin{array}{l}\text { Headache, nausea, } \\
\text { rash, vomiting and } \\
\text { fever }\end{array}$} & $\begin{array}{l}\text { Potential infectious agents' } \\
\text { transmission. } \\
\text { Thrombotic and } \\
\text { thromboembolic events. }\end{array}$ & {$[13,22,85,86]$} \\
\hline & & & & Allergic reactions. & SPC of the product \\
\hline & & & & Potential immunogenicity. & \\
\hline \multirow{3}{*}{$\begin{array}{l}\text { Low-volume } \\
\text { pdC1-INH }\end{array}$} & \multirow{3}{*}{$\begin{array}{l}\text { HAEGARDA, } \\
\text { CSL Behring }\end{array}$} & \multirow{3}{*}{$\begin{array}{l}\text { Adults and adolescents; } \\
60 \mathrm{IU} / \mathrm{kg} \text {, twice weekly, } \\
\text { S.C. }\end{array}$} & \multirow{3}{*}{$\begin{array}{l}\text { Injection site } \\
\text { reactions, } \\
\text { hypersensitivity, } \\
\text { nasopharyngitis, and } \\
\text { dizziness }\end{array}$} & $\begin{array}{l}\text { Potential infectious agents' } \\
\text { transmission. }\end{array}$ & \multirow{3}{*}{$\begin{array}{l}\text { SPC of the product } \\
\text { NCT01576523 } \\
\text { NCT01912456 } \\
\text { NCT02316353 }\end{array}$} \\
\hline & & & & $\begin{array}{l}\text { Potential thrombotic } \\
\text { events. }\end{array}$ & \\
\hline & & & & Potential tachyphylaxis. & \\
\hline \multirow{3}{*}{$\begin{array}{l}\text { Rh mAb } \\
\text { targeting plasma } \\
\text { kallikrein }\end{array}$} & \multirow{3}{*}{$\begin{array}{l}\text { Lanadelumab, } \\
\text { Shire }\end{array}$} & $\begin{array}{l}\text { Adults and adolescents; } \\
150 \mathrm{mg} \text {, once monthly, }\end{array}$ & \multirow{3}{*}{$\begin{array}{l}\text { Injection site } \\
\text { reactions, headache, } \\
\text { nasopharyngitis, rash, } \\
\text { and dizziness }\end{array}$} & Potential immunogenicity. & \multirow[b]{3}{*}{ Ongoing Phase III } \\
\hline & & $\begin{array}{l}\text { S.C. } \\
\text { or }\end{array}$ & & $\begin{array}{l}\text { Theoretical precaution for } \\
\text { cardiovascular accidents, }\end{array}$ & \\
\hline & & $\begin{array}{l}300 \mathrm{mg} \text {, once or twice } \\
\text { monthly, S.C. }\end{array}$ & & disorders & \\
\hline
\end{tabular}

rhC1-INH, recombinant human $\mathrm{C} 1$ inhibitor; pdC1-INH, plasma-derived $\mathrm{C} 1$ inhibitor; $\mathrm{HAE}$, hereditary angioedema; I.V., intravenously; S.C., subcutaneously; SPC, summary of product characteristics; rh, recombinant human; mAb, monoclonal antibody.

*Other prophylaxis options as androgens and tranexamic acid were not included as the data has been previously summarized in other review articles [89] 


\section{Annotated Bibliography:}

* - of interest

** - of considerable interest

1. Caccia S, Suffritti C, Cicardi M. Pathophysiology of Hereditary Angioedema. Pediatric allergy, immunology, and pulmonology, 27(4), 159-163 (2014).

2. Nussberger J, Cugno M, Amstutz C, Cicardi M, Pellacani A, Agostoni A. Plasma bradykinin in angio-oedema. Lancet, 351(9117), 1693-1697 (1998).

3. Nussberger J, Cugno M, Cicardi M. Bradykinin-mediated angioedema. N Engl J Med, 347(8), 621-622 (2002).

4. Rosen FS, Pensky J, Donaldson V, Charache P. Hereditary Angioneurotic Edema: Two Genetic Variants. Science, 148, 957-958 (1965).

5. Germenis AE, Speletas M. Genetics of Hereditary Angioedema Revisited. Clin Rev Allergy Immunol, (2016).

6. Jaradat SA, Caccia S, Rawashdeh $\mathrm{R}$ et al. Hereditary angioedema in a Jordanian family with a novel missense mutation in the $\mathrm{C} 1$-inhibitor $\mathrm{N}$-terminal domain. $\mathrm{Mol}$ Immunol, 71, 123-130 (2016).

7. Gabos G, Dobru D, Mihaly E et al. Recurrent ascites: a need to evaluate for hereditary angio-oedema. Lancet, 390(10107), 2119-2120 (2017).

8. Cicardi M, Aberer W, Banerji A et al. Classification, diagnosis, and approach to treatment for angioedema: consensus report from the Hereditary Angioedema International Working Group. Allergy, 69(5), 602-616 (2014).

9. Valerieva A. CM, Baraniuk J., Staevska M. The physician and hereditary angioedema friend or foe: 62-year diagnostic delay and iatrogenic procedures. Allergy Asthma Clin Immunol, in press (2018).

10. Bork K. Current management options for hereditary angioedema. Curr Allergy Asthma Rep, 12(4), 273-280 (2012).

11. Cicardi M, Bork K, Caballero $\mathrm{T}$ et al. Evidence-based recommendations for the therapeutic management of angioedema owing to hereditary $\mathrm{C} 1$ inhibitor deficiency: consensus report of an International Working Group. Allergy, 67(2), 147-157 (2012).

12. Craig TJ, Levy RJ, Wasserman RL et al. Efficacy of human $\mathrm{C} 1$ esterase inhibitor concentrate compared with placebo in acute hereditary angioedema attacks. J Allergy Clin Immunol, 124(4), 801-808 (2009).

13. Zuraw BL, Busse PJ, White $\mathrm{M}$ et al. Nanofiltered $\mathrm{C} 1$ inhibitor concentrate for treatment of hereditary angioedema. N Engl J Med, 363(6), 513-522 (2010).

14. Cicardi M, Banerji A, Bracho F et al. Icatibant, a new bradykinin-receptor antagonist, in hereditary angioedema. New England Journal of Medicine, 363(6), 532-541 (2010).

15. Zuraw B, Cicardi M, Levy RJ et al. Recombinant human C1-inhibitor for the treatment of acute angioedema attacks in patients with hereditary angioedema. $J$ Allergy Clin Immunol, 126(4), 821-827.e814 (2010). **

16. Reshef A, Kidon M, Leibovich I. The Story of Angioedema: from Quincke to Bradykinin. Clin Rev Allergy Immunol, 51(2), 121-139 (2016).

17. Riedl MA. Critical appraisal of androgen use in hereditary angioedema: a systematic review. Ann Allergy Asthma Immunol, 114(4), 281-288 e287 (2015).

18. Longhurst H, Cicardi M, Craig T et al. Prevention of Hereditary Angioedema Attacks with a Subcutaneous C1 Inhibitor. N Engl J Med, 376(12), 1131-1140 (2017). 
19. Banerji A, Busse P, Shennak $\mathrm{M}$ et al. Inhibiting Plasma Kallikrein for Hereditary Angioedema Prophylaxis. N Engl J Med, 376(8), 717-728 (2017).

20. Aygoren-Pursun E, Magerl M, Graff $\mathrm{J}$ et al. Prophylaxis of hereditary angioedema attacks: A randomized trial of oral plasma kallikrein inhibition with avoralstat. $J$ Allergy Clin Immunol, 138(3), 934-936 e935 (2016).

21. Rangarajan S, Walsh L, Lester W et al. AAV5-Factor VIII Gene Transfer in Severe Hemophilia A. N Engl J Med, 377(26), 2519-2530 (2017).

22. Cicardi M, Mannucci PM, Castelli R, Rumi MG, Agostoni A. Reduction in transmission of hepatitis $\mathrm{C}$ after the introduction of a heat-treatment step in the production of C1-inhibitor concentrate. Transfusion, 35(3), 209-212 (1995).

23. Terpstra FG, Kleijn M, Koenderman AH et al. Viral safety of C1-inhibitor NF. Biologicals, 35(3), 173-181 (2007).

24. Groner A. Pathogen safety of plasma-derived products - Haemate P/Humate-P. Haemophilia, 14 Suppl 5, 54-71 (2008).

25. Feussner A, Kalina U, Hofmann P, Machnig T, Henkel G. Biochemical comparison of four commercially available $\mathrm{C} 1$ esterase inhibitor concentrates for treatment of hereditary angioedema. Transfusion, (2014).

26. Bork K, Steffensen I, Machnig T. Treatment with C1-esterase inhibitor concentrate in type I or II hereditary angioedema: a systematic literature review. Allergy Asthma Proc, 34(4), 312-327 (2013).

27. Brettler DB. Recombinant coagulation factor products. Haemophilia, 1(3), 155-158 (1995).

28. Koles K, van Berkel PH, Pieper FR et al. N- and O-glycans of recombinant human C1 inhibitor expressed in the milk of transgenic rabbits. Glycobiology, 14(1), 51-64 (2004). *

29. Riedl MA, Bernstein JA, Li H et al. Recombinant human C1-esterase inhibitor relieves symptoms of hereditary angioedema attacks: Phase 3, randomized, placebocontrolled trial. Annals of Allergy, Asthma and Immunology, 112(2), 163-169.e161 (2014). **

30. Li HH, Moldovan D, Bernstein JA et al. Recombinant human-c1 inhibitor is effective and safe for repeat hereditary angioedema attacks. The journal of allergy and clinical immunology. In practice, 3(3), 417-423 (2015). **

31. Riedl MA, Levy RJ, Suez D et al. Efficacy and safety of recombinant C1 inhibitor for the treatment of hereditary angioedema attacks: a North American open-label study. Ann Allergy Asthma Immunol, 110(4), 295-299 (2013).

32. Moldovan D, Reshef A, Fabiani $\mathrm{J}$ et al. Efficacy and safety of recombinant human C1-inhibitor for the treatment of attacks of hereditary angioedema: European openlabel extension study. Clin Exp Allergy, 42(6), 929-935 (2012).

33. Riedl MA, Li HH, Cicardi M, Harper JR, Relan A. Recombinant human C1 esterase inhibitor for acute hereditary angioedema attacks with upper airway involvement. Allergy Asthma Proc, 38(6), 462-466 (2017). **

34. Reshef A, Moldovan D, Obtulowicz K et al. Recombinant human $\mathrm{C} 1$ inhibitor for the prophylaxis of hereditary angioedema attacks: a pilot study. Allergy, 68(1), 118-124 (2013). **

35. Farkas H, Kohalmi KV, Veszeli N, Zotter Z, Varga L. Successful prophylaxis with recombinant human $\mathrm{C} 1$ inhibitor in a patient with hereditary angioedema. Ann Allergy Asthma Immunol, 114(1), 64-65 (2015).

36. Davis AE, 3rd, Mejia P, Lu F. Biological activities of $\mathrm{C} 1$ inhibitor. Mol Immunol, 45(16), 4057-4063 (2008). 
37. Eldering E, Nuijens JH, Hack CE. Expression of functional human $\mathrm{C} 1$ inhibitor in COS cells. J Biol Chem, 263(24), 11776-11779 (1988).

38. Aulak KS, Eldering E, Hack CE et al. A hinge region mutation in $\mathrm{C} 1$-inhibitor (Ala436-->Thr) results in nonsubstrate-like behavior and in polymerization of the molecule. J Biol Chem, 268(24), 18088-18094 (1993).

39. Bos IG, de Bruin EC, Karuntu YA, Modderman PW, Eldering E, Hack CE. Recombinant human $\mathrm{C} 1$-inhibitor produced in Pichia pastoris has the same inhibitory capacity as plasma C1-inhibitor. Biochim Biophys Acta, 1648(1-2), 75-83 (2003).

40. Demain AL, Vaishnav P. Production of recombinant proteins by microbes and higher organisms. Biotechnol Adv, 27(3), 297-306 (2009).

41. Houdebine LM. Production of pharmaceutical proteins by transgenic animals. Comp Immunol Microbiol Infect Dis, 32(2), 107-121 (2009).

42. van Doorn MB, Burggraaf J, van Dam T et al. A phase I study of recombinant human $\mathrm{C} 1$ inhibitor in asymptomatic patients with hereditary angioedema. J Allergy Clin Immunol, 116(4), 876-883 (2005). **

43. van Veen HA, Koiter J, Vogelezang CJ et al. Characterization of recombinant human C1 inhibitor secreted in milk of transgenic rabbits. Journal of biotechnology, 162(23), 319-326 (2012).*

44. Perkins SJ, Smith KF, Amatayakul S et al. Two-domain structure of the native and reactive centre cleaved forms of $\mathrm{C} 1$ inhibitor of human complement by neutron scattering. J Mol Biol, 214(3), 751-763 (1990).

45. Odermatt E, Berger H, Sano Y. Size and shape of human C1-inhibitor. FEBS Lett, 131(2), 283-285 (1981).

46. Strecker G, Ollier-Hartmann MP, van Halbeek H, Vliegenthart JF, Montreuil J, Hartmann L. [Primary structure of the glycan chains of normal C 1 esterase inhibitor (C 1-INH) after NMR analysis at $400 \mathrm{MHz}$. C R Acad Sci III, 301(11), 571-576 (1985).

47. Silverman GA, Bird PI, Carrell RW et al. The serpins are an expanding superfamily of structurally similar but functionally diverse proteins. Evolution, mechanism of inhibition, novel functions, and a revised nomenclature. J Biol Chem, 276(36), 3329333296. (2001).

48. Davis AE, 3rd. C1 inhibitor and hereditary angioneurotic edema. Annu Rev Immunol, 6, 595-628 (1988).

49. Davis AE, 3rd, Cai S, Liu D. C1 inhibitor: biologic activities that are independent of protease inhibition. Immunobiology, 212(4-5), 313-323 (2007).

50. Davis B, Tang J, Zhang L et al. Role of vasodilator stimulated phosphoprotein in VEGF induced blood-brain barrier permeability in endothelial cell monolayers. Int $J$ Dev Neurosci, 28(6), 423-428 (2010).

51. Minta JO. The role of sialic acid in the functional activity and the hepatic clearance of C1-INH. J Immunol, 126(1), 245-249 (1981).

52. Suffritti C, Zanichelli A, Maggioni L, Bonanni E, Cugno M, Cicardi M. Highmolecular-weight kininogen cleavage correlates with disease states in the bradykininmediated angioedema due to hereditary C1-inhibitor deficiency. Clin Exp Allergy, 44(12), 1503-1514 (2014).

53. Moldovan D, Bernstein JA, Cicardi M. Recombinant replacement therapy for hereditary angioedema due to C1 inhibitor deficiency. Immunotherapy, 7(7), 739-752 (2015).

54. Zanichelli A, Arcoleo F, Barca MP et al. A nationwide survey of hereditary angioedema due to $\mathrm{C} 1$ inhibitor deficiency in Italy. Orphanet journal of rare diseases, $10,11(2015)$. 
55. van den Elzen MT, van Os-Medendorp $\mathrm{H}$, Rockmann-Helmbach $\mathrm{H}$ et al. Allergenicity and safety of recombinant human $\mathrm{C} 1$ esterase inhibitor in patients with allergy to rabbit or cow's milk. J Allergy Clin Immunol, 138(2), 476-481 e471 (2016). **

56. Martinez-Saguer I, Rusicke E, Aygoren-Pursun E, von Hentig N, Klingebiel T, Kreuz W. Pharmacokinetic analysis of human plasma-derived pasteurized C1-inhibitor concentrate in adults and children with hereditary angioedema: a prospective study. Transfusion, 50(2), 354-360 (2010).

57. Hack CE, Relan A, van Amersfoort ES, Cicardi M. Target levels of functional C1inhibitor in hereditary angioedema. Allergy, 67(1), 123-130 (2012). *

58. Farrell C, Hayes S, Relan A, van Amersfoort ES, Pijpstra R, Hack CE. Population pharmacokinetics of recombinant human $\mathrm{C} 1$ inhibitor in patients with hereditary angioedema. Br J Clin Pharmacol, 76(6), 897-907 (2013). *

59. Choi G, Soeters MR, Farkas H et al. Recombinant human C1-inhibitor in the treatment of acute angioedema attacks. Transfusion, 47(6), 1028-1032 (2007). **

60. Pharming. Press release. (2017).

61. Relan A, Bakhtiari K, van Amersfoort ES, Meijers JC, Hack CE. Recombinant C1inhibitor: effects on coagulation and fibrinolysis in patients with hereditary angioedema. BioDrugs, 26(1), 43-52 (2012).

62. Reshef A, Zanichelli A, Longhurst H, Relan A, Hack CE. Elevated D-dimers in attacks of hereditary angioedema are not associated with increased thrombotic risk. Allergy, 70(5), 506-513 (2015).

63. Hack CE, Relan A, Baboeram A et al. Immunosafety of recombinant human C1inhibitor in hereditary angioedema: evaluation of ige antibodies. Clinical drug investigation, 33(4), 275-281 (2013).

64. Eldering E, Huijbregts CC, Lubbers YT, Longstaff C, Hack CE. Characterization of recombinant C1 inhibitor P1 variants. J Biol Chem, 267(10), 7013-7020 (1992).

65. Bos IG, Lubbers YT, Roem D, Abrahams JP, Hack CE, Eldering E. The functional integrity of the serpin domain of $\mathrm{C} 1$-inhibitor depends on the unique $\mathrm{N}$-terminal domain, as revealed by a pathological mutant. J Biol Chem, 278(32), 29463-29470 (2003).

66. Gesuete R, Storini C, Fantin A et al. Recombinant C1 inhibitor in brain ischemic injury. Ann Neurol, 66(3), 332-342 (2009).

67. Orsini F, Villa P, Parrella S et al. Targeting mannose-binding lectin confers longlasting protection with a surprisingly wide therapeutic window in cerebral ischemia. Circulation, 126(12), 1484-1494 (2012).

68. Bergamaschini L, Gobbo G, Gatti S et al. Endothelial targeting with C1-inhibitor reduces complement activation in vitro and during ex vivo reperfusion of pig liver. Clin Exp Immunol, 126(3), 412-420. (2001).

69. Moller-Kristensen M, Wang W, Ruseva M et al. Mannan-binding lectin recognizes structures on ischaemic reperfused mouse kidneys and is implicated in tissue injury. Scand J Immunol, 61(5), 426-434 (2005).

70. Storini C, Rossi E, Marrella V et al. C1-inhibitor protects against brain ischemiareperfusion injury via inhibition of cell recruitment and inflammation. Neurobiol Dis, 19(1-2), 10-17 (2005).

71. Inderbitzin D, Beldi G, Avital I, Vinci G, Candinas D. Local and remote ischemiareperfusion injury is mitigated in mice overexpressing human c1 inhibitor. Eur Surg Res, 36(3), 142-147 (2004). 
72. Pedersen ED, Waje-Andreassen U, Vedeler CA, Aamodt G, Mollnes TE. Systemic complement activation following human acute ischaemic stroke. Clin Exp Immunol, 137(1), 117-122 (2004).

73. Chan RK, Ibrahim SI, Verna N, Carroll M, Moore FD, Jr., Hechtman HB. Ischaemiareperfusion is an event triggered by immune complexes and complement. Br J Surg, 90(12), 1470-1478 (2003).

74. De Simoni MG, Storini C, Barba M et al. Neuroprotection by complement (C1) inhibitor in mouse transient brain ischemia. J Cereb Blood Flow Metab, 23(2), 232239 (2003).

75. van der Pol P, Schlagwein N, van Gijlswijk DJ et al. Mannan-binding lectin mediates renal ischemia/reperfusion injury independent of complement activation. $\mathrm{Am} \mathrm{J}$ Transplant, 12(4), 877-887 (2012).

76. Norwood MG, Sayers RD, Roscher S, Lynch NJ, Sutton AJ, Schwaeble WJ. Consumption of mannan-binding lectin during abdominal aortic aneurysm repair. Eur J Vasc Endovasc Surg, 31(3), 239-243 (2006).

77. Longhi L, Perego C, Ortolano F et al. C1-inhibitor attenuates neurobehavioral deficits and reduces contusion volume after controlled cortical impact brain injury in mice. Crit Care Med, (2009).

78. Botto M. Links between complement deficiency and apoptosis. Arthritis Res, 3(4), 207-210 (2001).

79. Bernstein JA, Ritchie B, Levy RJ et al. Population pharmacokinetics of plasmaderived $\mathrm{C} 1$ esterase inhibitor concentrate used to treat acute hereditary angioedema attacks. Ann Allergy Asthma Immunol, 105(2), 149-154 (2010).

80. Kreuz W, Martinez-Saguer I, Aygoren-Pursun E, Rusicke E, Heller C, Klingebiel T. $\mathrm{C} 1$-inhibitor concentrate for individual replacement therapy in patients with severe hereditary angioedema refractory to danazol prophylaxis. Transfusion, 49(9), 19871995 (2009).

81. Waytes AT, Rosen FS, Frank MM. Treatment of hereditary angioedema with a vaporheated C1 inhibitor concentrate. N Engl J Med, 334(25), 1630-1634. (1996).

82. Wuillemin WA, Eldering E, Citarella F, de Ruig CP, ten Cate H, Hack CE. Modulation of contact system proteases by glycosaminoglycans. Selective enhancement of the inhibition of factor XIa. J Biol Chem, 271(22), 12913-12918 (1996).

83. Baker JW, Reshef A, Moldovan D, Harper JR, Relan A, Riedl MA. Recombinant Human C1-Esterase Inhibitor to Treat Acute Hereditary Angioedema Attacks in Adolescents. The journal of allergy and clinical immunology. In practice, (2017).

84. Hack CE, Mannesse M, Baboeram A, Oortwijn B, Relan A. Immunogenicity assessment of recombinant human c1-inhibitor: an integrated analysis of clinical studies. BioDrugs, 26(5), 303-313 (2012).

85. Greve J, Hahn J, Nordmann $\mathrm{M}$ et al. Nanofiltrated C1-esterase-inhibitor in the prophylactic treatment of bradykinin-mediated angioedema. Transfusion, (2016).

86. Caballero $\mathrm{T}$, Farkas $\mathrm{H}$, Bouillet $\mathrm{L}$ et al. International consensus and practical guidelines on the gynecologic and obstetric management of female patients with hereditary angioedema caused by $\mathrm{C} 1$ inhibitor deficiency. J Allergy Clin Immunol, 129(2), 308-320 (2012).

87. Zuraw BL, Cicardi M, Longhurst HJ et al. Phase II study results of a replacement therapy for hereditary angioedema with subcutaneous $\mathrm{C} 1$-inhibitor concentrate. Allergy, 70(10), 1319-1328 (2015).

88. Chyung Y, Vince B, Iarrobino $\mathrm{R}$ et al. A phase 1 study investigating DX-2930 in healthy subjects. Ann Allergy Asthma Immunol, 113(4), 460-466 e462 (2014). 
89. Wu MA, Zanichelli A, Mansi M, Cicardi M. Current treatment options for hereditary angioedema due to $\mathrm{C} 1$ inhibitor deficiency. Expert Opinion on Pharmacotherapy, 17(1), 27-40 (2016). 


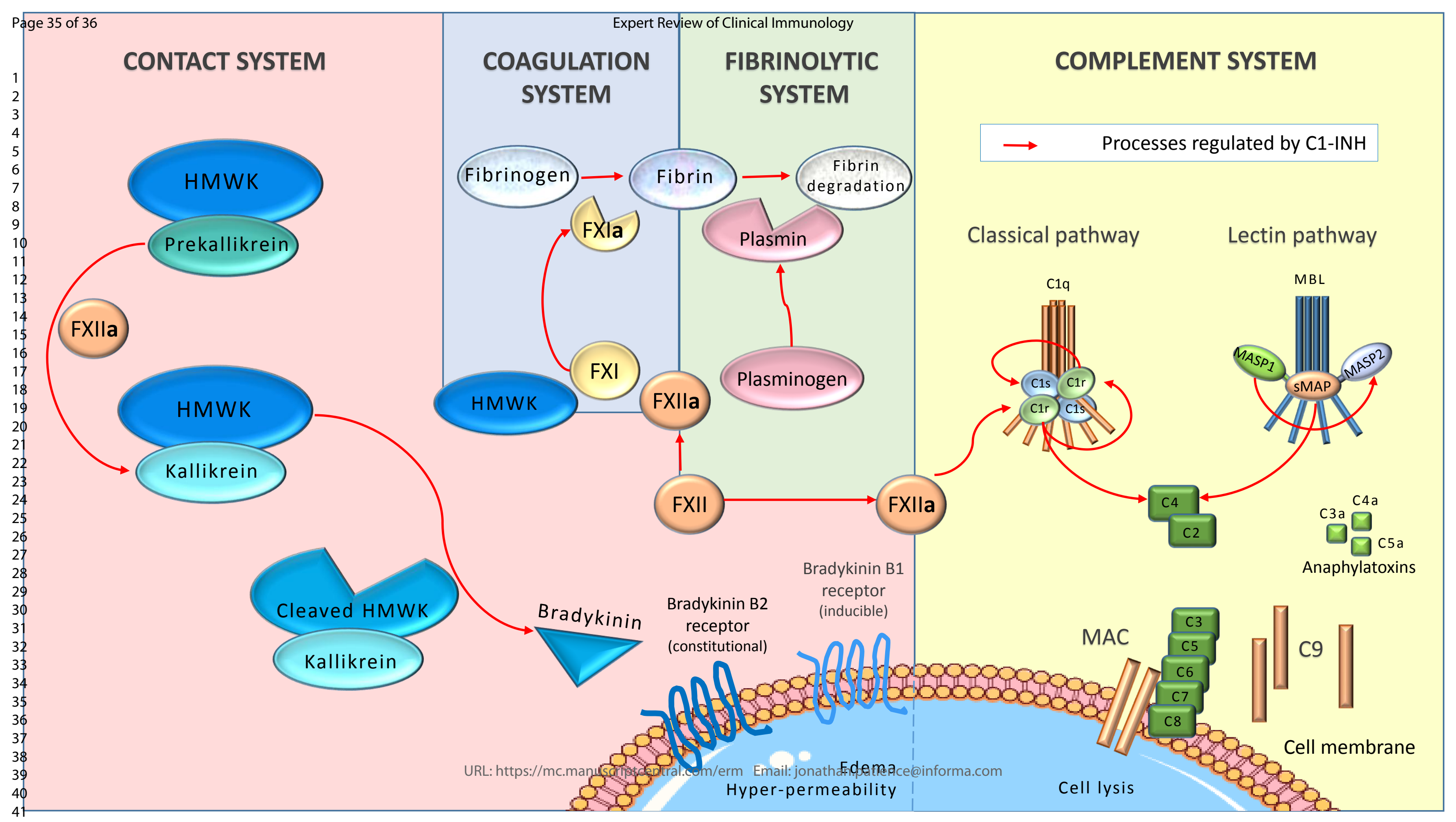


